\title{
Immune Modulating Peptides for the Treatment and Suppression of Multiple Sclerosis
}

\author{
Ahmed H. Badawi ${ }^{1}$ and Teruna J. Siahaan ${ }^{1,2}$ \\ ${ }^{1}$ Department of Pharmaceutical Chemistry, University of Kansas, Lawrence, KS 66047
}

Abstract

Multiple sclerosis (MS) is a neurodegenerative disease in which the immune system recognizes proteins of the myelin sheath as antigenic, thus initiating an inflammatory reaction in the central nervous system. This leads to demyelination of the axons, breakdown of the blood-brain barrier, and lesion formation. Current therapies for the treatment of MS are generally non-specific and weaken the global immune system, thus making the individual susceptible to opportunistic infections. Antigenic peptides and their derivatives are becoming more prevalent for investigation as therapeutic agents for MS because they possess immune-specific characteristics. In addition, other peptides that target vital components of the inflammatory immune response have also been developed. Therefore, the objectives of this review are to (a) summarize the immunological basis for the development of MS, (b) discuss specific and non-specific peptides tested in EAE and in humans, and (c) briefly address some problems and potential solutions with these novel therapies.

\section{Keywords}

Multiple Sclerosis; Experimental Autoimmune Encephalomyelitis; Peptide; Antigen; Bifunctional Peptide Inhibitor

\section{MULTPLE SCLEROSIS}

\subsection{Disease Introduction}

Multiple sclerosis (MS) is the most common immune-mediated disease of the central nervous system. It is characterized by severe demyelination, axonal injury, lesion formation in the brain and spinal cord, blood-brain barrier (BBB) opening, and inflammatory immune cell infiltration [1]. MS is a very heterogeneous disease with very diverse pathological and clinical manifestations. Some of the clinical symptoms include loss of balance and coordination, visual and sensory impairment, fatigue, and cognitive difficulties [2]. The pathogenesis of the disease is not well understood, and there are a multitude of factors that may cause the onset of this disease. Genetic factors may play a major role, and it has been shown that a particular class-II allele of the major histocompatibility complex (MHC) may increase the risk for developing MS [3, 4]. Other studies have indicated a correlation between pathogenic infections and the development of the disease. This is believed to be

\footnotetext{
(C) 2012 Elsevier Inc. All rights reserved.

${ }^{2}$ Address correspondence to: Teruna J. Siahaan, Department of Pharmaceutical Chemistry, The University of Kansas, 2095 Constant Avenue, Lawrence, Kansas 66047, Phone: 785-864-7327, Fax: 785-864-5736, siahaan@ ku.edu.

Publisher's Disclaimer: This is a PDF file of an unedited manuscript that has been accepted for publication. As a service to our customers we are providing this early version of the manuscript. The manuscript will undergo copyediting, typesetting, and review of the resulting proof before it is published in its final citable form. Please note that during the production process errors may be discovered which could affect the content, and all legal disclaimers that apply to the journal pertain.
} 
caused by a phenomenon known as molecular mimicry or bystander activation [5]. Some links have been made between various different viruses to MS, such as the Epstein-Barr virus [6,7] and varicella zoster virus [8], as well as bacterial pathogens such as chlamydia pneumonia [9-11]. However, there is no direct evidence of the link between pathogenic infections and MS. Currently, the most widely accepted hypothesis is that MS is an autoimmune disease that affects genetically pre-disposed individuals afflicted with an environmental pathogen [12].

Diagnosis of MS is complicated and unfortunately the majority of the current treatments are non-specific. The most common diagnostic tool for MS is magnetic resonance imaging (MRI). MRI has become a very important tool in diagnosis and monitoring of disease progression and is crucial for devising proper treatment plans. It is used to look for white matter lesion formation, particularly in the pons and the cerebellum [13], and the development of "black holes" that are a hallmark of severe demyelination and axonal damage [14]. There are currently eight FDA-approved therapies for the treatment of MS. Four forms of IFN- $\beta$ therapies are being used for treatment, but their mechanism of action remains unknown [15]. It is believed that they work primarily by inducing an antiinflammatory response [16]. Another commonly used therapeutic agent is glatiramer acetate (Copaxone), which is a polymer made up of a random mixture of four amino acids (alanine, glutamic acid, lysine, and tyrosine) [17]. The proposed mechanism of action of Copaxone is the diversion of the $T$ cell response from type- $1\left(T_{H} 1\right)$ to type- 2 helper $\left(T_{H} 2\right) T$ cells. Mitoxantrone is an alternative drug that works primarily by inhibiting the proliferation of immune cells [16]. A monoclonal antibody (mAb) called natalizumab (Tysabri) is also being used to treat MS; it binds the a $4 \beta 1$ integrin [18] to inhibit the migration of lymphocytes into the $\mathrm{BBB}$, thus preventing the infiltration of immune cells into the central nervous systems (CNS). Fingolimod (Gilenya), which prevents lymphocytes from exiting the lymph nodes and keeping them at the periphery so they cannot reach the CNS, is the latest FDA-approved drug [19].

\subsection{Cellular Mechanisms and Role of Cytokines}

The body has protective mechanisms in the thymus to prevent and eliminate any autoreactive $\mathrm{T}$ cells by a process known as central tolerance [20]. If autoreactive $\mathrm{T}$ cells fail to become tolerant by resident antigen presenting cells (APC) in the thymus, they can escape to the periphery, thus making the individual susceptible for the development of an autoimmune disease. However, the body has back-up protective peripheral-tolerance mechanisms to prevent these autoreactive T cells from proliferating and attacking selfcomponents [21]. In the case of MS, it is proposed that both the central and peripheral tolerance mechanisms fail to induce tolerance or anergy to myelin-specific T cells. Furthermore, under yet unknown conditions, these myelin-reactive T cells can cross the $\mathrm{BBB}$ to enter the CNS via adhesion molecule interactions [22, 23]. Once in the CNS, these T cells become re-activated by resident APC such as microglia, macrophages, and dendritic cells (DC) and induce an inflammatory response in the CNS [20,24]. DC play a crucial but contradictory role in the body; they are important both for maintaining peripheral tolerance and inducing an immunogenic response. It has been reported that DC can pick up myelin proteins and present them to T cells in the periphery [25-27]. DC have a strong presence in the inflammatory lesions of MS patients [28] and thus are key players in the reactivation of autoreactive T cells in the CNS [29]. In addition, DC have been implicated in epitope spreading [30]. The contribution of B cells to the development and progress of MS is not very clear. However, a phase II clinical trial using rituximab, a monoclonal antibody which depletes B cells, was beneficial to MS patients, therefore suggesting that B cells have a role in the pathogenesis of disease [31], and myelin-specific antibodies have been found in the cerebrospinal fluid (CSF) of MS patients [32]. 
In the past, MS was believed to be solely a $\mathrm{CD} 4^{+} \mathrm{T}_{\mathrm{H}} 1$ disease; recently, evidence has strongly suggested that $\mathrm{CD} 4^{+}$type-17 $\mathrm{T}$ cells $\left(\mathrm{T}_{\mathrm{H}} 17\right)$ have a key role in its pathogenesis [33]. The contribution of $\mathrm{T}_{\mathrm{H}} 17$ and/or $\mathrm{T}_{\mathrm{H}} 1$ cells to the disease has not been fully elucidated, but the balance between these two $\mathrm{T}$ cell subsets has an important role in determining the location of the lesions within the brain [24]. MS is traditionally thought to be purely a $\mathrm{CD} 4^{+}$-mediated disease with little appreciation of the contribution of $\mathrm{CD}^{+} \mathrm{T}$ cells. Myelinspecific $\mathrm{CD} 8^{+} \mathrm{T}$ cells have been found in greater amounts in the lesions of MS patients but not healthy individuals [34-36]; this is unlike myelin-specific $\mathrm{CD} 4^{+} \mathrm{T}$ cells, which are found in both MS and healthy individuals [37]. In addition, the depletion of $\mathrm{CD}^{+}$cells has no effect on disease progression, but depletion of both $\mathrm{CD} 4^{+}$and $\mathrm{CD} 8^{+} \mathrm{T}$ cells has beneficial effects [38]. Like $\mathrm{CD} 4^{+}, \mathrm{CD} 8^{+} \mathrm{T}$ cells are activated in the periphery and can cross the $\mathrm{BBB}$ under inflammatory conditions. Activation of $\mathrm{CD} 8^{+}$in the periphery is accomplished through cross-presentation, which means APC that do not synthesize myelin proteins can present antigens to $\mathrm{CD} 8^{+} \mathrm{T}$ cells in the context of the MHC-I molecule [39]. Activation in the CNS occurs via resident APC, and it still remains unclear which types of $\mathrm{APC}$ are involved [24]. CD8 ${ }^{+} \mathrm{T}$ cells exert their effector function in the CNS through the production of soluble inflammatory mediators as well as direct cell lysis [24, 34, 35]. Therefore, contributions from both $\mathrm{CD} 4^{+}$and $\mathrm{CD}^{+}$are probably important in the development and pathogenesis of disease, and the different involvement of both $\mathrm{T}$ cells is proposed to be the reason behind the broad heterogeneity of the disease [24]. Autoreactive T cells can recognize several proteins of the myelin sheath as antigenic. The most common antigenic proteins in MS patients are myelin basic protein (MBP); myelin proteolipid protein (PLP), which makes up 50\% of total myelin protein; and myelin oligodendrocyte glycoprotein (MOG), which is found on the outside of myelin sheath [5]. Identifying these autoantigens has become important for developing antigen-specific therapies as well as for induction of the disease in animal models for studying MS.

Currently, the widely accepted model for T-cell activation and induction of an inflammatory response is the "two-signal" model $[40,41]$. The model proposes that two signals, an antigen-specific and a "danger" signal, must be delivered to T cells by APC such as an activated or mature DC ( $\mathrm{mDC}$ ). The maturation of an immature DC (iDC) is triggered by the phagocytosis of an insoluble antigen [42, 43]. Next, the antigen is broken down into small peptides, processed, and presented by the APC to a T cell via the MHC-II/T cell receptor (TCR) interaction; this is known as Signal 1. During the maturation process, the phenotype of DC changes and expresses costimulatory molecules and adhesion molecules on its surface (Figure 1). The presence of the costimulatory molecules, also known as Signal 2, informs the $\mathrm{T}$ cell of "danger" and, thus, the $\mathrm{T}$ cell differentiates into a pro-inflammatory phenotype to initiate an inflammatory response. One of the most important costimulatory signals is delivered via the B7/CD28 protein interaction and is a positive or activation signal $[44,45]$. This interaction is vital for the activation of T cells in MS and its animal model, experimental autoimmune encephalomyelitis (EAE). A second pair of costimulatory molecules that have been shown to have a major role in the development of helper $\mathrm{T}$ cells are the CD40/CD154 (also referred to as CD40/CD40L) receptors [46]. A study in B7deficient mice showed that the CD40/CD154 signal can sufficiently deliver the costimulatory signal in the absence of the B7/CD28 interaction [47]. Inhibitory (negative) signals can be delivered to $\mathrm{T}$ cells to inhibit its activation via the B7/CTLA-4 interaction [48]. Cell adhesion molecules also function to activate $\mathrm{T}$ cells, most notable molecules are intercellular adhesion molecule-1 (ICAM-1) and leukocyte function-associated antigen-1 (LFA-1) [49]. Another important group of molecules, which play a big role in influencing the $\mathrm{T}_{\mathrm{H}} 1 / \mathrm{T}_{\mathrm{H}} 2$ balance in MS, are the inducible costimulator (ICOS) molecule and its ligand (ICOSL) [50]. It has been reported in the EAE model, that the ICOS/ICOSL interaction can induce mucosal tolerance by upregulating $\mathrm{T}_{\mathrm{H}} 2$ and regulatory cytokines [51, 52]. Following the delivery of Signal 1 and 2, a phenomenon known as the immunological synapse (IS) 
must take place to complete the activation of T cells [53, 54]. The formation of the IS involves the translocation between Signal 1 molecules (TCR/MHC-II-Ag complex) and the adhesion molecules (ICAM-1/LFA-1 complex). Because it is believed that the formation of the IS is vital for the activation of T cells, IS could be an important target for developing therapeutics aimed at suppressing the immune response.

All the immune responses involved in the pathogenesis and treatment of MS are mediated via a complex network of cytokines. During steady-state conditions (i.e., homeostasis), there is a balance between pro- and anti-inflammatory cytokines. In MS, inflammatory cytokines are responsible for the pathogenesis of the disease in the periphery as well as within the CNS. The function of each cytokine has not been fully elucidated due to the dynamic network and complex nature of the cytokine milieu. For the development and progression of disease, the pro-inflammatory cytokines are key players. There are several cytokines involved in the inflammatory response, particularly $\mathrm{T}_{\mathrm{H}} 1$ cytokines such as IL-12, IFN- $\gamma$, and TNF- $a$ as well as $\mathrm{T}_{\mathrm{H}} 17$ cytokines such as IL-23 and IL-17 [24]. The exact contribution of each of these cytokines remains unclear and difficult to sort out. The involvement of IL-12 and IFN- $\gamma$ was established by their heightened expression in the CNS and CSF of MS patients with increased clinical activity [55]. In addition, the roles of TNF- $a$ and IFN- $\gamma$ were determined when peripheral blood mononuclear cells (PBMC) isolated from MS patients secreted significant amounts of them [56-61]. IL-17 transcripts were found in CNS lesions of MS patients, thus indicating a major role of IL-17 in disease pathogenesis [33]. Immunotolerance is believed to be maintained by a group of suppressor $\left(\mathrm{T}_{\mathrm{H}} 2\right)$ and regulatory $T$ cells $\left(\mathrm{T}_{\text {reg }}\right.$ ) that produce anti-inflammatory cytokines such as IL-2, IL-4, and IL-10 [62]. During the disease state, it has been reported that PBMC isolated from MS patients secrete no or low amounts of the anti-inflammatory cytokines [62]. Moreover, during ongoing disease there is a shift towards the production of pro-inflammatory cytokines. Therefore, a major strategy for treating an inflammatory disease like MS is shifting the balance towards the production of anti-inflammatory cytokines such as the ones secreted by $\mathrm{T}_{\text {reg }}$ and $\mathrm{T}_{\mathrm{H}} 2$ cells.

\subsection{Experimental Autoimmune Encephalomyelitis}

The EAE animal model is used to study the underlying disease pathogenesis of MS and develop new therapies. EAE can be induced either by adoptive transfer of myelin-specific $\mathrm{T}$ cells or by the administration of a CNS homogenate or specific myelin proteins/peptides in the presence of an adjuvant such as complete Freund's adjuvant (CFA) [63]. In order to facilitate EAE induction and produce more reliable and consistent disease, pertussis toxin can be injected following the CFA/antigen injection [64]. Also, more recently, a new clone of transgenic mice possessing PLP $139-151$ specific TCR has been shown to develop spontaneous EAE [65]. The EAE model mimics MS in several ways such as the development of multiple CNS lesions, destruction of the myelin sheath, and the breakdown of the BBB. Similar to MS, various immune cells are involved in the disease pathogenesis. Macrophages, microglia cells, DC, B-cell antibodies, and both $\mathrm{CD} 4^{+}$and $\mathrm{CD} 8^{+}$have vital roles in the development of the inflammatory response and tissue destruction [66]. The model has been very useful in studying the mode of action of four therapies currently on the market for the treatment of MS such as glatiramer acetate (Copaxone) [67], mitoxantrone [68], natalizumab (Tysabri) [69], and, most recently, fingolimod (Gilenya) [70-74]. It is important to recognize the limitations of the animal model as most successes in that model did not translate to humans [75]. In addition, many of the adverse side effects observed in clinical trials, from therapies initially tested in EAE, could not have been predicted from the animal model [76]. No one model of EAE mimics the heterogeneous pathology of MS and, therefore, more work must be done in order to more closely mimic the human disease. Nevertheless, EAE played a key role in understanding many pathogenic aspects of the 
disease and led to the development of four important MS therapeutics; thus, its contribution in the past must not be undermined. For these reasons, the EAE animal model is continuously being used to test and develop new therapies for MS.

\section{PEPTIDE TREATMENTS FOR MS}

Most of the current therapies for MS do not regulate specific immune cells and they normally suppress the general immune response, which leads to many adverse side effects from opportunistic infections. Thus, there is a need to develop therapeutic agents that specifically control the myelin-reactive immune response for maintaining host capability to protect against foreign pathogens provided by the general immune response. Peptides are excellent specific inhibitors of protein-protein interactions and, therefore, are valuable specific modulators of protein-mediated signaling of the immune system. In this section, many of the current myelin-specific peptides being tested for the treatment of MS will be discussed. In addition, important advances in the development of non-specific peptides that have efficacy in the EAE animal model will be discussed.

\subsection{Antigenic Peptides}

Specific immunotherapy (SIT) has been used for about a century to induce tolerance for the treatment of allergies such as hay fever [77] and, more recently, seasonal allergic rhinitis [78], asthma [79], bee venom [80], peanuts [81], cow milk [82], and birch pollen [83]. The strategy behind allergen- or antigen-SIT is to administer the antigenic protein/peptide in a proper dose to modulate the immune response and reduce the immunogenicity towards a particular allergen/antigen [84]. The goal of SIT is to induce $\mathrm{T}$ cell anergy, activate $\mathrm{T}_{\text {reg }}$, or promote a shift from a $\mathrm{T}_{\mathrm{H}} 1$ phenotype to $\mathrm{T}_{\mathrm{H}} 2$ phenotype [85]. Translating this strategy for inducing tolerance to treat autoimmune diseases has been the focus of many research groups. In this section, the successes of antigenic-SIT in the MS animal model and difficulties in applying the technology to humans will be discussed. In addition, some of the mechanistic aspects of this therapy will be discussed.

Tolerance induction via the mucosal route has been studied extensively in the EAE model. There are numerous studies showing that oral administration of myelin proteins or peptides is an effective way for inducing tolerance, by causing either T cell clonal anergy or induction of the regulatory immune response. It is reported that this depends on the dose of the administered antigen [86-88]. The attractive aspect of the oral route is that it mimics naturally induced tolerance to ingested antigens (with the exception of food allergies), in addition to its ease of administration. Studies reporting suppression of disease with whole proteins has been reported $[89,90]$ and, more importantly, there are numerous studies showing that induction of tolerance to suppress EAE can be achieved using small protein fragments and peptides. In one study, MBP fragments (1-37, 44-89, and 90-170) suppressed the disease significantly [91]. The oral administration of guinea pig- $\mathrm{MBP}_{68-88}$ suppressed rat-MBP $68-88$-induced EAE in Lewis rats [92]. Other reports showed that MBP and MBP peptide suppressed PLP-induced EAE, suggesting that bystander suppression is possible via the oral route [93]. Lastly, another study showed that feeding animals with PLP $_{139-151}$ peptide induced T-cell clonal anergy and prevented the onset of EAE [94]. Unfortunately, the success in the EAE animal model could not be translated to MS patients. One phase-III clinical trial conducted to test the efficacy of orally administered bovinemyelin containing MBP and PLP showed no significant difference between the treatment and placebo groups (reviewed in ref. [95]). Thus, even though studies conducted in humans have proven that administration of antigen via the oral route is a safe method, no studies have reported any significant benefit so far. The other mucosal route used to deliver antigens is nasal administration. Studies using MBP whole protein [96, 97], MBP peptides [98], and a mixture of myelin peptides $\left(\mathrm{PLP}_{139-151}, \mathrm{MBP}_{1-11}, \mathrm{MBP}_{89-101}\right)$ [99] have induced peripheral 
tolerance and prevented the onset of EAE but, similar to the oral route, no significant benefit in humans has been reported.

Other routes that have been more successful in attenuating MS and EAE were intravenous (i.v.) and transdermal administration. There have been several reports indicating the successful suppression of EAE after i.v. administration of MOG (41-60) and MBP peptides [100] and whole MBP [101, 102]. When the $\mathrm{MBP}_{82-98}$ peptide fragment was tested in MS patients, it generally reduced anti-MBP antibodies and significantly delayed the progression of disease in a particular sub-group of MS patients with the HLA haplotype DR2/DR4 [103]. Another study indicated that i.v. administration of $\mathrm{MBP}_{85-96}$, but not intrathecal or subcutaneous administration, led to undetectable amounts of MBP autoantibodies in the CSF for several months post-treatment [104]. More recently, transdermal delivery of myelin antigens has shown some clinical benefit following the success observed in EAE. MBP $_{A c 1-11}$ [105] and whole MBP [106] delivered transdermally protected mice from developing EAE. A small study conducted in patients diagnosed with relapsing-remitting MS was performed to test the immunological modulation caused by a mixture of three peptides $\left(\mathrm{MBP}_{85-99}, \mathrm{MOG}_{35-55}\right.$, and $\left.\mathrm{PLP}_{139-151}\right)$ via an adhesive skin patch. Myelin-specific $T$ cell responses were completely eliminated after only four months of treatment [107]. In addition, there was an up-regulation in the production of IL-10 and a down-regulation of TGF- $\beta$ and IFN- $\gamma$ in the MS patients, indicating a shift towards an immunotolerant state. These results are promising and may show clinical efficacy if tested on a larger scale. So far, translating efficacy from the EAE animal model to MS treatment has proven to be a difficult task. This is probably due to the complexity and heterogeneity of human autoimmune diseases. Many factors must be considered when trying to apply antigenic-SIT for the treatment of human autoimmune disease such as dosing amount and frequency, route of administration, and specificity of antigens administered.

As described previously, the inflammatory response is initiated by a $\mathrm{mDC}$ due to exposure to an insoluble antigen. The uptake and processing of an insoluble antigen leads to the activation of a DC and the presentation of the antigen in presence of costimulatory molecules, thus inducing an inflammatory response. The immunological basis for antigenicpeptide therapy is that when the peptide is given in a soluble state, it binds directly to empty MHC-II molecules on the surface of iDC [108]. Because iDC do not have surface costimulatory molecules, the presentation of antigen by the MHC-II on an iDC in the absence of costimulatory signal(s) causes the naïve $\mathrm{T}$ cells to differentiate to $\mathrm{T}_{\text {reg }}$ cells after their interactions with antigen-presenting iDC [43]. Activation and proliferation of $\mathrm{T}_{\text {reg }}$ cells influences the balance of the immune response to restore tolerance by shifting from an effector $\mathrm{T}$ cell response $\left(\mathrm{T}_{\mathrm{H}} 1\right)$ to an immune-suppressor $\left(\mathrm{T}_{\mathrm{H}} 2\right)$ or an immune-regulatory response (Figure 2).

\subsection{Altered Peptide Ligands}

Altered peptide ligands (APL) are another group of peptides that are proposed to cause antigen-specific immunosuppression. These are molecules that are similar in sequence to native peptides with one or more amino acid modification(s) and can bind to MHC-II molecules and engage with the TCR to alter or inhibit the delivery of signal to the T cell. Thus, these molecules act as antagonists to produce $\mathrm{T}$ cell anergy or as partial agonists to produce incomplete activation of $\mathrm{T}$ cells. Incomplete activation of $\mathrm{T}$ cells will cause a shift from a pro-inflammatory $\mathrm{T}$ cell response $\left(\mathrm{T}_{\mathrm{H}} 1\right.$ and $\left.\mathrm{T}_{\mathrm{H}} 17\right)$ to a regulatory/suppressor $\mathrm{T}$ cell response $\left(\mathrm{T}_{\mathrm{H}} 2\right.$ and $\left.\mathrm{T}_{\mathrm{H}} 3\right)$ [109]. APL with sequence modifications in $\mathrm{MBP}_{1-9}$ [110], MBP $_{87-99}[111,112]$, and PLP $_{139-151}$ [113-117] have been shown to attenuate disease in the EAE model. In a phase I clinical trial, an APL from $\mathrm{MBP}_{83-99}$ showed a $\mathrm{T}_{\mathrm{H}} 2$ bias and produced anti-inflammatory cytokines; the peptide was well-tolerated by the patients in this trial [118]. However, when this APL was tested in two separate phase II clinical trials, there 
was no significant clinical benefit seen in treated patients $[119,120]$. In one of the clinical trials, there was no difference observed in the small group of treated patients and the study was terminated due to adverse side effects from the treatment; in addition 3 of 8 patients experienced exacerbations of disease [119]. In the other clinical trial, hypersensitivity reactions were also present and no clinical differences between the APL-treated and the placebo groups were observed, albeit there was a reduction in the number and volume of gadolinium-enhanced CNS lesions [120].

Glatiramer acetate (Copaxone) is a random polymer of four amino acids (poly $(\mathrm{YEAK})_{\mathrm{n}}$ ) that has been shown to modulate the immune response by competing with MBP epitopes for MHC binding as well as causing TCR antagonism [121]. Therefore, it is the only APL on the market for the treatment of MS. Following the success of Copaxone, similar molecules have been developed and tested in the EAE model. A poly(EYYK $)_{4}$ peptide that was developed to bind to the MHC-II binding pocket was shown to inhibit EAE in Lewis rats [122]. Other molecules such as poly $(\mathrm{FYAK})_{\mathrm{n}}$ and poly $(\mathrm{VWAK})_{\mathrm{n}}$ also ameliorated both MBP $_{85-99}$ - and PLP $139-152$-induced EAE in mice $[123,124]$. However, one study indicated that Copaxone has no beneficial effects on disease progression and the risk of developing relapses; and therefore, its clinical use may be questionable [125]. It should also be noted that the efficacy observed from these short amino acid polymers in the animal model may not be translatable to humans.

\subsection{Bifunctional Peptide Inhibitors}

Our group has developed a novel group of bifunctional peptide inhibitors (BPI), which target APC and are proposed to selectively inhibit an immunogenic response towards a specific antigen. BPI molecules are composed of an antigenic peptide covalently linked to an adhesion peptide [126]. It is proposed that the antigenic peptide fragment of the BPI molecule binds to MHC-II molecules and the adhesion peptide binds simultaneously to an adhesion protein on the surface of the APC. The linker is made up of either aminocaproic acid or polyethylene glycol (PEG) to ensure simultaneous binding of the antigenic peptide portion as well as the adhesion peptide (LABL) to their respective receptors on the surface of the APC. The original length of the linker was estimated upon docking of the antigenic peptide and LABL peptide to X-ray structures of MHC-II [127] and ICAM-1, respectively [128-130]. As mentioned earlier, a step necessary for the activation of a pro-inflammatory $\mathrm{T}$ cell response is the formation of the immunological synapse, which occurs at the interface of APC and T cells and is the translocation of Signal 1 and adhesion proteins [40, 41, 53, 54]. The hypothesis is that BPI molecules bind to both MHC-II (Signal 1) and ICAM-1 (adhesion protein) on the surface of APC to tether both molecules and prevent the formation of the immunological synapse, thus altering the differentiation and proliferation of $\mathrm{T}$ cells from an inflammatory to a regulatory phenotype.

Several BPI molecules consisting of various antigens and adhesion peptides have been developed for the suppression of autoimmune diseases in animal models. A GAD-BPI molecule composed of $\mathrm{GAD}_{208-217}$ and LABL peptides suppressed Type-1 diabetes in the non-obese diabetes mouse model [131]. GAD-BPI significantly suppressed insulitis and lowered blood glucose levels compared to control. Currently, CII-BPI composed of a collagen-II antigenic peptide $\left(\mathrm{CII}_{256-270}, \mathrm{CII}_{707-721}\right.$, or $\left.\mathrm{CII}_{1237-1249}\right)$ conjugated to LABL peptide attenuated clinical signs of rheumatoid arthritis in the collagen-II-induced model (unpublished data). More importantly, PLP-BPI, composed of PLP 139-151 $_{1}$ conjugated to LABL, was the first BPI molecule to suppress EAE and modulate the immune response by increasing the proliferation of TGF- $\beta$-, IL-4-, and IL-10-producing CD $4{ }^{+} \mathrm{CD} 25^{+} \mathrm{T}$ cells, indicating a shift towards a suppressor and regulatory immune response [132-134]. Other studies with PLP-BPI showed that it can also suppress disease when injected three times (s.c.), or when dosed in a controlled release fashion [135]. Current studies prove that PLP- 
BPI is effective when administered prior to induction of disease, or even after the appearance of clinical signs. Recently, PLP-cIBR, which contains cIBR7 peptide from the D1 domain of ICAM-1, was shown to be more potent than the parent PLP-BPI. A new MOG-BPI molecule composed of $\mathrm{MOG}_{38-50}$ can suppress MOG-induced EAE in the mouse model. Finally, a multivalent BPI molecule composed of both $\mathrm{MOG}_{38-50}$ and PLP $139-151$ has been shown to suppress disease significantly in both $\mathrm{MOG}_{38-50^{-}}$and $\mathrm{PLP}_{139-151^{-i n d u c e d}}$ EAE. The value of the multivalent BPI molecule is that it can suppress disease regardless of the inciting antigen as well as attenuate new antigenic responses created by epitope spreading.

In summary, BPI molecules have excellent efficacy in suppressing EAE and other autoimmune diseases in animal models. Current studies indicate that BPI molecules downregulate the production of pro-inflammatory cytokines and increase the production of regulatory cytokines. These results suggest that BPI molecules promote a shift towards a regulatory and suppressor immune response. However, more studies need to be done to elucidate the mechanisms of action of BPI molecules.

\subsection{Other Peptides}

A novel group of non-antigen-specific peptide inhibitors that bind to B7 on the surface of $\mathrm{T}$ cells and prevent the delivery of the costimulatory signal are derived from the sequence of the CD28 costimulatory protein on the surface of APC [44, 45]. The presentation of an antigen in the absence of a costimulatory signal will lead to T cell anergy, therefore inhibiting the inflammatory response (Figure 3). Peptides derived from the conserved region of CD28 containing the motif MYPPPY bind to B7 and have suppressed EAE in B10.PL mice [136]. A similar but shorter peptide that showed efficacy in prolonging cardiac allograft rejection [137] was tested in our laboratory, and results indicated significant suppression of PLP 139 -151-induced EAE in SJL/J mice (unpublished data).

Another approach to suppressing the immune response is targeting the CD4 molecule on the surface of $\mathrm{CD}^{+} \mathrm{T}$ cells. $\mathrm{CD} 4^{+} \mathrm{T}$ cells are known to have a key role in the pathogenesis of disease and, therefore, preventing their activation would be a valuable target for attenuating any $\mathrm{CD}^{+}{ }^{-}$-mediated immune response such as in MS. A cyclic peptide complementary to the CDR3-like region of CD4 [138] and another peptide designed based on the D1-CC ${ }^{\prime}$ loop region [139] were developed and found to suppress EAE effectively. However, it must be noted that safety will be a major concern when developing molecules that target molecules like CD4, since the CD4 molecule is important for the general immune defense mechanisms. Another immunomodulatory peptide known as RDP58 inhibits $T_{H} 1$ cytokines [140] as well as upregulates heme-oxygenase-1 [141, 142]. It has been shown that heme-oxyhenase-1 has a protective role in EAE $[143,144]$; therefore, when combined with the inhibition of $\mathrm{T}_{\mathrm{H}} 1$ cytokines, RDP58 significantly lowered the incidence of EAE in Lewis rats [145].

Recently, new peptides have been developed for the treatment of MS by evaluating them in EAE animal models. First, IIIM1 is a 9-amino acid peptide derived from histone $\mathrm{H}_{2} \mathrm{~A}_{36-44}$ that possesses anti-inflammatory activity and suppressed MOG- and PLP-induced EAE $[146,147]$. When administered orally, this peptide reduced the production of proinflammatory cytokines such as IL-17, IFN- $\gamma$, IL12, and IL-23 and promoted $\mathrm{T}_{\text {reg }}$ cell proliferation accompanied by an increase in TGF- $\beta$ and IL-10 production. Secondly, four peptides that bind to the first two extracellular loops (ECL1 and ECL2) of the CC chemokine receptor 5 (CCR5) have been shown to significantly reduce the infiltration of monocytes and lymphocytes into the spinal cord and attenuated EAE in mice [148]. CCR5 has been shown to contribute significantly to the pathogenesis of disease by its role in the activation and migration of leukocytes [149]. Peptides targeting CCR5 have a mechanism of action similar to that of Tysabri, a monoclonal antibody used for the treatment of MS [150]. 
Thirdly, glucocorticoid-induced leucine zipper- (GILZ) peptides that bind to nuclear factorkappa B (NF- $\mathrm{\kappa B}$ ) can modulate T-cell activation and induce an anti-inflammatory immune response to suppress the progression of EAE in mice [151]. GILZ peptides were derived from the binding sequence of GILZ to the p65 subunit of NF- $\mathrm{kB}$ [151]. GILZ-peptides inhibit the function of NF- $\mathrm{KB}$ and suppress the activation of inflammatory cytokines [152]. Finally, it has recently been proposed that treatment of MS can be achieved by modulating toll-like receptors (TLR) because TLR play an integral part in the development of MS and EAE [153-156]. Gambuzza et al. described different types of TLR that are involved in progression of MS and EAE and illustrated several peptides that modulate TLR and can potentially suppress disease [156].

\section{SAFETY CONCERNS}

A major safety concern involving antigen or antigen-derived therapies is the risk of developing anaphylaxis, which is a severe hypersensitivity reaction. Two clinical trials with an APL were terminated due to hypersensitivity reactions that developed in the patients $[119,120]$. An anaphylactic reaction can occur from the initial burst of immune cell activation and proliferation accompanied by a storm of cytokine release. The generally accepted mechanism for induction of anaphylaxis is due to the release of inflammatory mediators that are triggered by cross-linking of IgE molecules bound to FceRI on mast cells. This can lead to life-threatening symptoms such as tissue edema, leukocyte recruitment, excessive mucous production, and bronchoconstriction [157, 158]. Anaphylaxis has been observed in numerous EAE models after treatment with myelin peptides [159, 160], but when the peptides were administered in combination with an anti-IgE antibody, onset of anaphylaxis was inhibited. The route of administering the peptides plays a major role in mitigating the risk of developing hypersensitivity reactions. It is thought that i.v. injections have the greatest risk for developing anaphylaxis since the antigen becomes accessible to the systemic circulation immediately. S.c. and intradermal injections are believed to have a lower incidence of anaphylaxis, and mucosal administration is the safest [109]. It should be noted, however that induction of EAE by priming with myelin peptide in the presence of CFA leads to the production of IgE molecules [161], thus fostering a hypersensitivity response. This is in contrast to what occurs in MS patients, in which there is production of IgG antibodies [104]. To prevent side effects, Wraith et al. suggested that antigenic peptides could be delivered in a fashion similar to the way that allergens are delivered for the treatment of allergies [84]. In this case, the antigenic peptide should be administered by gradually increasing the dose to avoid rapid induction of anergy or activation of $\mathrm{T}_{\text {reg }}$ that leads to side effects.

\section{CONCLUSIONS}

MS pathogenesis is very complex, involving many different branches of the immune system, and still remains to be fully elucidated. Current treatments for MS are generally nonspecific, leading to suppression of the general immune response to fight pathogenic infections. Therefore, there is a need to develop more antigen-specific treatments that avoid this general suppression. Recently, antigen-specific treatments such as antigenic peptides, APL, and bifunctional peptide inhibitors have been very successful in suppressing EAE in animal models. Unfortunately, many of these successes in animal models have not been yet translated to humans in treating MS; this is partly due to the generation of hypersensitivity reactions upon treatment with the antigenic peptides. In addition, the mechanisms of action of antigenic peptides and their derivatives in suppressing autoimmune diseases such as EAE and MS are not yet fully understood. Thus, more research needs to be done to elucidate their mechanisms of action and delineate why these antigenic peptides and their derivatives induce side effects such as hypersensitivity reactions. It has been shown that the method of 
delivery and dosing schedule could reduce side effects. In the future, studies performed to develop novel delivery methods and dosing schedules of antigenic peptide therapies will be carried out to improve the efficacy and safety profiles of peptide therapies for MS.

\section{Acknowledgments}

We would like to thank the National Institutes of Health (R01-AI-063002, R56-AI-063002, and T32-NIH-066335) for supporting this work. We are also grateful to Nancy Harmony for her help in proofreading this manuscript.

\section{Abbreviations}
EAE experimental autoimmune encephalomyelitis
BPI bifunctional peptide inhibitor

\section{References}

1. Lassmann H. Classification of demyelinating diseases at the interface between etiology and pathogenesis. Curr Opin Neurol. 2001; 14:253-258. [PubMed: 11371746]

2. McFarland HF, Martin R. Multiple sclerosis: a complicated picture of autoimmunity. Nat Immunol. 2007; 8:913-919. [PubMed: 17712344]

3. Compston A. The genetic epidemiology of multiple sclerosis, Philosophical transactions of the Royal Society of London. Series B. Biological sciences. 1999; 354:1623-1634. [PubMed: 10603615]

4. Lincoln MR, Montpetit A, Cader MZ, Saarela J, Dyment DA, Tiislar M, Ferretti V, Tienari PJ, Sadovnick AD, Peltonen L, Ebers GC, Hudson TJ. A predominant role for the HLA class II region in the association of the MHC region with multiple sclerosis. Nature genetics. 2005; 37:1108-1112. [PubMed: 16186814]

5. Sospedra M, Martin R. Immunology of multiple sclerosis. Annu Rev Immunol. 2005; 23:683-747. [PubMed: 15771584]

6. Pender MP. Does Epstein-Barr virus infection in the brain drive the development of multiple sclerosis? Brain. 2009; 132:3196-3198. [PubMed: 20008341]

7. Bagert BA. Epstein-Barr virus in multiple sclerosis. Current neurology and neuroscience reports. 2009; 9:405-410. [PubMed: 19664371]

8. Gilden DH. Infectious causes of multiple sclerosis. Lancet neurology. 2005; 4:195-202. [PubMed: 15721830]

9. Gaydos CA. Chlamydia pneumoniae and its proposed link to multiple sclerosis: to be or not to be? Neurology. 2001; 56:1126-1127. [PubMed: 11342673]

10. Jacobson S, Cross A. Association of Chlamydia pneumoniae and multiple sclerosis: stage two? Neurology. 2001; 56:1128-1129. [PubMed: 11342674]

11. Yao SY, Ljunggren-Rose A, Stratton CW, Mitchell WM, Sriram S. Regulation by IFN-beta of inducible nitric oxide synthase and interleukin-12/p40 in murine macrophages cultured in the presence of Chlamydia pneumoniae antigens. Journal of interferon \& cytokine research : the official journal of the International Society for Interferon and Cytokine Research. 2001; 21:137146.

12. Kenealy SJ, Pericak-Vance MA, Haines JL. The genetic epidemiology of multiple sclerosis. J Neuroimmunol. 2003; 143:7-12. [PubMed: 14575907]

13. Ormerod IE, Miller DH, McDonald WI, du Boulay EP, Rudge P, Kendall BE, Moseley IF, Johnson G, Tofts PS, Halliday AM, et al. The role of NMR imaging in the assessment of multiple sclerosis and isolated neurological lesions. A quantitative study. Brain. 1987; 110(Pt 6):1579-1616. [PubMed: 3427402]

14. van Walderveen MA, Kamphorst W, Scheltens P, van Waesberghe JH, Ravid R, Valk J, Polman $\mathrm{CH}$, Barkhof F. Histopathologic correlate of hypointense lesions on T1-weighted spin-echo MRI in multiple sclerosis. Neurology. 1998; 50:1282-1288. [PubMed: 9595975] 
15. Yong VW, Chabot S, Stuve O, Williams G. Interferon beta in the treatment of multiple sclerosis: mechanisms of action. Neurology. 1998; 51:682-689. [PubMed: 9748010]

16. Derwenskus J. Current disease-modifying treatment of multiple sclerosis. The Mount Sinai journal of medicine, New York. 2011; 78:161-175.

17. Arnon R. The development of Cop 1 (Copaxone), an innovative drug for the treatment of multiple sclerosis: personal reflections. Immunol Lett. 1996; 50:1-15. [PubMed: 8793553]

18. Ransohoff RM. Natalizumab for multiple sclerosis. N Engl J Med. 2007; 356:2622-2629. [PubMed: 17582072]

19. Horga A, Castillo J, Montalban X. Fingolimod for relapsing multiple sclerosis: an update. Expert opinion on pharmacotherapy. 2010; 11:1183-1196. [PubMed: 20367536]

20. Stoeckle C, Tolosa E. Antigen processing and presentation in multiple sclerosis. Results Probl Cell Differ. 2010; 51:149-172. [PubMed: 19582405]

21. Goodnow CC, Sprent J, Fazekas de St Groth B, Vinuesa CG. Cellular and genetic mechanisms of self tolerance and autoimmunity. Nature. 2005; 435:590-597. [PubMed: 15931211]

22. Butcher EC, Picker LJ. Lymphocyte homing and homeostasis. Science. 1996; 272:60-66. [PubMed: 8600538]

23. Ransohoff RM, Kivisakk P, Kidd G. Three or more routes for leukocyte migration into the central nervous system. Nat Rev Immunol. 2003; 3:569-581. [PubMed: 12876559]

24. Goverman J. Autoimmune T cell responses in the central nervous system. Nat Rev Immunol. 2009; 9:393-407. [PubMed: 19444307]

25. Marty MC, Alliot F, Rutin J, Fritz R, Trisler D, Pessac B. The myelin basic protein gene is expressed in differentiated blood cell lineages and in hemopoietic progenitors. Proc Natl Acad Sci U S A. 2002; 99:8856-8861. [PubMed: 12084930]

26. Karman J, Ling C, Sandor M, Fabry Z. Initiation of immune responses in brain is promoted by local dendritic cells. J Immunol. 2004; 173:2353-2361. [PubMed: 15294948]

27. Hatterer E, Touret M, Belin MF, Honnorat J, Nataf S. Cerebrospinal fluid dendritic cells infiltrate the brain parenchyma and target the cervical lymph nodes under neuroinflammatory conditions. PLoS One. 2008; 3:e3321. [PubMed: 18830405]

28. Serafini B, Rosicarelli B, Magliozzi R, Stigliano E, Capello E, Mancardi GL, Aloisi F. Dendritic cells in multiple sclerosis lesions: maturation stage, myelin uptake, and interaction with proliferating T cells. J Neuropathol Exp Neurol. 2006; 65:124-141. [PubMed: 16462204]

29. Greter M, Heppner FL, Lemos MP, Odermatt BM, Goebels N, Laufer T, Noelle RJ, Becher B. Dendritic cells permit immune invasion of the CNS in an animal model of multiple sclerosis. Nat Med. 2005; 11:328-334. [PubMed: 15735653]

30. McMahon EJ, Bailey SL, Castenada CV, Waldner H, Miller SD. Epitope spreading initiates in the CNS in two mouse models of multiple sclerosis. Nat Med. 2005; 11:335-339. [PubMed: 15735651]

31. Hauser SL, Waubant E, Arnold DL, Vollmer T, Antel J, Fox RJ, Bar-Or A, Panzara M, Sarkar N, Agarwal S, Langer-Gould A, Smith CH. B-cell depletion with rituximab in relapsing-remitting multiple sclerosis. N Engl J Med. 2008; 358:676-688. [PubMed: 18272891]

32. Kabat EA, Freedman DA, et al. A study of the crystalline albumin, gamma globulin and total protein in the cerebrospinal fluid of 100 cases of multiple sclerosis and in other diseases. Am J Med Sci. 1950; 219:55-64. [PubMed: 15402305]

33. Lock C, Hermans G, Pedotti R, Brendolan A, Schadt E, Garren H, Langer-Gould A, Strober S, Cannella B, Allard J, Klonowski P, Austin A, Lad N, Kaminski N, Galli SJ, Oksenberg JR, Raine CS, Heller R, Steinman L. Gene-microarray analysis of multiple sclerosis lesions yields new targets validated in autoimmune encephalomyelitis. Nat Med. 2002; 8:500-508. [PubMed: 11984595]

34. Goverman J, Perchellet A, Huseby ES. The role of CD8(+) T cells in multiple sclerosis and its animal models. Curr Drug Targets Inflamm Allergy. 2005; 4:239-245. [PubMed: 15853746]

35. Friese MA, Fugger L. Autoreactive CD8+ T cells in multiple sclerosis: a new target for therapy? Brain. 2005; 128:1747-1763. [PubMed: 15975943] 
36. Junker A, Ivanidze J, Malotka J, Eiglmeier I, Lassmann H, Wekerle H, Meinl E, Hohlfeld R, Dornmair K. Multiple sclerosis: T-cell receptor expression in distinct brain regions. Brain. 2007; 130:2789-2799. [PubMed: 17890278]

37. Crawford MP, Yan SX, Ortega SB, Mehta RS, Hewitt RE, Price DA, Stastny P, Douek DC, Koup RA, Racke MK, Karandikar NJ. High prevalence of autoreactive, neuroantigen-specific CD8+ T cells in multiple sclerosis revealed by novel flow cytometric assay. Blood. 2004; 103:4222-4231. [PubMed: 14976054]

38. Coles AJ, Cox A, Le Page E, Jones J, Trip SA, Deans J, Seaman S, Miller DH, Hale G, Waldmann $\mathrm{H}$, Compston DA. The window of therapeutic opportunity in multiple sclerosis: evidence from monoclonal antibody therapy. J Neurol. 2006; 253:98-108. [PubMed: 16044212]

39. Perchellet A, Brabb T, Goverman JM. Crosspresentation by nonhematopoietic and direct presentation by hematopoietic cells induce central tolerance to myelin basic protein. Proc Natl Acad Sci U S A. 2008; 105:14040-14045. [PubMed: 18772374]

40. Grakoui A, Bromley SK, Sumen C, Davis MM, Shaw AS, Allen PM, Dustin ML. The immunological synapse: a molecular machine controlling T cell activation. Science. 1999; 285:221-227. [PubMed: 10398592]

41. Tseng SY, Dustin ML. T-cell activation: a multidimensional signaling network. Curr Opin Cell Biol. 2002; 14:575-580. [PubMed: 12231352]

42. Jonuleit H, Schmitt E, Schuler G, Knop J, Enk AH. Induction of interleukin 10-producing, nonproliferating $\mathrm{CD} 4(+) \mathrm{T}$ cells with regulatory properties by repetitive stimulation with allogeneic immature human dendritic cells. J Exp Med. 2000; 192:1213-1222. [PubMed: 11067871]

43. Larche M, Wraith DC. Peptide-based therapeutic vaccines for allergic and autoimmune diseases. Nat Med. 2005; 11:S69-76. [PubMed: 15812493]

44. Jenkins MK, Johnson JG. Molecules involved in T-cell costimulation. Curr Opin Immunol. 1993; 5:361-367. [PubMed: 7688514]

45. June CH, Bluestone JA, Nadler LM, Thompson CB. The B7 and CD28 receptor families. Immunol Today. 1994; 15:321-331. [PubMed: 7522010]

46. Schonbeck U, Libby P. The CD40/CD154 receptor/ligand dyad. Cell Mol Life Sci. 2001; 58:4-43. [PubMed: 11229815]

47. Girvin AM, Dal Canto MC, Miller SD. CD40/CD40L interaction is essential for the induction of EAE in the absence of CD28-mediated co-stimulation. J Autoimmun. 2002; 18:83-94. [PubMed: 11908941]

48. McCoy KD, Le Gros G. The role of CTLA-4 in the regulation of T cell immune responses. Immunol Cell Biol. 1999; 77:1-10. [PubMed: 10101680]

49. Valitutti S, Dessing M, Aktories K, Gallati H, Lanzavecchia A. Sustained signaling leading to T cell activation results from prolonged $\mathrm{T}$ cell receptor occupancy. Role of $\mathrm{T}$ cell actin cytoskeleton. J Exp Med. 1995; 181:577-584. [PubMed: 7836913]

50. Wiendl H, Neuhaus O, Mehling M, Wintterle S, Schreiner B, Mitsdoerffer M, Wienhold W, Weissert R, Wessels J, Hartung HP, Weller M, Tolosa E, Melms A. The CD28 related molecule ICOS: T cell modulation in the presence and absence of B7.1/2 and regulational expression in multiple sclerosis. J Neuroimmunol. 2003; 140:177-187. [PubMed: 12864987]

51. Miyamoto K, Kingsley CI, Zhang X, Jabs C, Izikson L, Sobel RA, Weiner HL, Kuchroo VK, Sharpe AH. The ICOS molecule plays a crucial role in the development of mucosal tolerance. $\mathrm{J}$ Immunol. 2005; 175:7341-7347. [PubMed: 16301640]

52. Galicia G, Kasran A, Uyttenhove C, De Swert K, Van Snick J, Ceuppens JL. ICOS deficiency results in exacerbated IL-17 mediated experimental autoimmune encephalomyelitis. J Clin Immunol. 2009; 29:426-433. [PubMed: 19291374]

53. Lee KH, Holdorf AD, Dustin ML, Chan AC, Allen PM, Shaw AS. T cell receptor signaling precedes immunological synapse formation. Science. 2002; 295:1539-1542. [PubMed: 11859198]

54. van der Merwe PA. Formation and function of the immunological synapse. Curr Opin Immunol. 2002; 14:293-298. [PubMed: 11973125]

55. Gutcher I, Becher B. APC-derived cytokines and T cell polarization in autoimmune inflammation. J Clin Invest. 2007; 117:1119-1127. [PubMed: 17476341] 
56. Cannella B, Raine CS. The adhesion molecule and cytokine profile of multiple sclerosis lesions. Ann Neurol. 1995; 37:424-435. [PubMed: 7536402]

57. Hirsch RL, Panitch HS, Johnson KP. Lymphocytes from multiple sclerosis patients produce elevated levels of gamma interferon in vitro. J Clin Immunol. 1985; 5:386-389. [PubMed: 3936865]

58. Maimone D, Reder AT, Gregory S. T cell lymphokine-induced secretion of cytokines by monocytes from patients with multiple sclerosis. Cell Immunol. 1993; 146:96-106. [PubMed: 8425234]

59. Merrill JE, Strom SR, Ellison GW, Myers LW. In vitro study of mediators of inflammation in multiple sclerosis. J Clin Immunol. 1989; 9:84-96. [PubMed: 2541163]

60. Selmaj K, Raine CS, Cannella B, Brosnan CF. Identification of lymphotoxin and tumor necrosis factor in multiple sclerosis lesions. J Clin Invest. 1991; 87:949-954. [PubMed: 1999503]

61. Ozenci V, Kouwenhoven M, Huang YM, Kivisakk P, Link H. Multiple sclerosis is associated with an imbalance between tumour necrosis factor-alpha (TNF-alpha)- and IL-10-secreting blood cells that is corrected by interferon-beta (IFN-beta) treatment. Clin Exp Immunol. 2000; 120:147-153. [PubMed: 10759776]

62. Mouzaki A, Tselios T, Papathanassopoulos P, Matsoukas I, Chatzantoni K. Immunotherapy for multiple sclerosis: basic insights for new clinical strategies. Curr Neurovasc Res. 2004; 1:325340. [PubMed: 16181082]

63. Racke MK. Experimental autoimmune encephalomyelitis (EAE). Curr Protoc Neurosci. 2001; Chapter 9(Unit9-7)

64. Constantinescu, CS.; Hilliard, BA. Adjuvants in EAE. In: Ehud Lavi, CSC., editor. Experimental Models of Multiple Sclerosis. Springer; 2005. p. 73-84.

65. Waldner H, Whitters MJ, Sobel RA, Collins M, Kuchroo VK. Fulminant spontaneous autoimmunity of the central nervous system in mice transgenic for the myelin proteolipid proteinspecific T cell receptor. Proc Natl Acad Sci U S A. 2000; 97:3412-3417. [PubMed: 10737797]

66. Gold R, Linington C, Lassmann H. Understanding pathogenesis and therapy of multiple sclerosis via animal models: 70 years of merits and culprits in experimental autoimmune encephalomyelitis research. Brain. 2006; 129:1953-1971. [PubMed: 16632554]

67. Teitelbaum D, Meshorer A, Hirshfeld T, Arnon R, Sela M. Suppression of experimental allergic encephalomyelitis by a synthetic polypeptide. Eur J Immunol. 1971; 1:242-248. [PubMed: 5157960]

68. Lublin FD, Lavasa M, Viti C, Knobler RL. Suppression of acute and relapsing experimental allergic encephalomyelitis with mitoxantrone. Clin Immunol Immunopathol. 1987; 45:122-128. [PubMed: 3621681]

69. Yednock TA, Cannon C, Fritz LC, Sanchez-Madrid F, Steinman L, Karin N. Prevention of experimental autoimmune encephalomyelitis by antibodies against alpha 4 beta 1 integrin. Nature. 1992; 356:63-66. [PubMed: 1538783]

70. Chiba K, Kataoka H, Seki N, Shimano K, Koyama M, Fukunari A, Sugahara K, Sugita T. Fingolimod (FTY720), sphingosine 1-phosphate receptor modulator, shows superior efficacy as compared with interferon-beta in mouse experimental autoimmune encephalomyelitis. International immunopharmacology. 2011; 11:366-372. [PubMed: 20955831]

71. Chun J, Hartung HP. Mechanism of action of oral fingolimod (FTY720) in multiple sclerosis. Clinical neuropharmacology. 2010; 33:91-101. [PubMed: 20061941]

72. Papadopoulos D, Rundle J, Patel R, Marshall I, Stretton J, Eaton R, Richardson JC, Gonzalez MI, Philpott KL, Reynolds R. FTY720 ameliorates MOG-induced experimental autoimmune encephalomyelitis by suppressing both cellular and humoral immune responses. J Neurosci Res. 2010; 88:346-359. [PubMed: 19658199]

73. Kataoka H, Sugahara K, Shimano K, Teshima K, Koyama M, Fukunari A, Chiba K. FTY720, sphingosine 1-phosphate receptor modulator, ameliorates experimental autoimmune encephalomyelitis by inhibition of T cell infiltration. Cellular \& molecular immunology. 2005; 2:439-448. [PubMed: 16426494] 
74. Fujino M, Funeshima N, Kitazawa Y, Kimura H, Amemiya H, Suzuki S, Li XK. Amelioration of experimental autoimmune encephalomyelitis in Lewis rats by FTY720 treatment. J Pharmacol Exp Ther. 2003; 305:70-77. [PubMed: 12649354]

75. Baker D, Gerritsen W, Rundle J, Amor S. Critical appraisal of animal models of multiple sclerosis. Mult Scler. 2011; 17:647-657. [PubMed: 21372117]

76. Baxter AG. The origin and application of experimental autoimmune encephalomyelitis. Nat Rev Immunol. 2007; 7:904-912. [PubMed: 17917672]

77. Noon L. Prophylactic inoculation against hay fever. Historical document. Ann Allergy. 1960; 18:287-291. [PubMed: 14427539]

78. Durham SR, Walker SM, Varga EM, Jacobson MR, O’Brien F, Noble W, Till SJ, Hamid QA, Nouri-Aria KT. Long-term clinical efficacy of grass-pollen immunotherapy. N Engl J Med. 1999; 341:468-475. [PubMed: 10441602]

79. Bousquet J, Lockey R, Malling HJ, Alvarez-Cuesta E, Canonica GW, Chapman MD, Creticos PJ, Dayer JM, Durham SR, Demoly P, Goldstein RJ, Ishikawa T, Ito K, Kraft D, Lambert PH, Lowenstein H, Muller U, Norman PS, Reisman RE, Valenta R, Valovirta E, Yssel H. Allergen immunotherapy: therapeutic vaccines for allergic diseases. World Health Organization. American academy of Allergy, Asthma and Immunology. Ann Allergy Asthma Immunol. 1998; 81:401-405. [PubMed: 9860031]

80. Akdis CA, Akdis M, Blesken T, Wymann D, Alkan SS, Muller U, Blaser K. Epitope-specific T cell tolerance to phospholipase A2 in bee venom immunotherapy and recovery by IL-2 and IL-15 in vitro. J Clin Invest. 1996; 98:1676-1683. [PubMed: 8833918]

81. Jones SM, Pons L, Roberts JL, Scurlock AM, Perry TT, Kulis M, Shreffler WG, Steele P, Henry KA, Adair M, Francis JM, Durham S, Vickery BP, Zhong X, Burks AW. Clinical efficacy and immune regulation with peanut oral immunotherapy. J Allergy Clin Immunol. 2009; 124:292-300. [PubMed: 19577283]

82. Skripak JM, Nash SD, Rowley H, Brereton NH, Oh S, Hamilton RG, Matsui EC, Burks AW, Wood RA. A randomized, double-blind, placebo-controlled study of milk oral immunotherapy for cow's milk allergy. J Allergy Clin Immunol. 2008; 122:1154-1160. [PubMed: 18951617]

83. Mobs C, Slotosch C, Loffler H, Jakob T, Hertl M, Pfutzner W. Birch pollen immunotherapy leads to differential induction of regulatory $\mathrm{T}$ cells and delayed helper $\mathrm{T}$ cell immune deviation. $\mathrm{J}$ Immunol. 2010; 184:2194-2203. [PubMed: 20048125]

84. Sabatos-Peyton CA, Verhagen J, Wraith DC. Antigen-specific immunotherapy of autoimmune and allergic diseases. Curr Opin Immunol. 2010; 22:609-615. [PubMed: 20850958]

85. McDevitt H. Specific antigen vaccination to treat autoimmune disease. Proc Natl Acad Sci U S A. 2004; 101(Suppl 2):14627-14630. [PubMed: 15466699]

86. Friedman A, Weiner HL. Induction of anergy or active suppression following oral tolerance is determined by antigen dosage. Proc Natl Acad Sci U S A. 1994; 91:6688-6692. [PubMed: 8022835]

87. Faria AM, Weiner HL. Oral tolerance: mechanisms and therapeutic applications. Adv Immunol. 1999; 73:153-264. [PubMed: 10399007]

88. Weiner HL, Friedman A, Miller A, Khoury SJ, al-Sabbagh A, Santos L, Sayegh M, Nussenblatt RB, Trentham DE, Hafler DA. Oral tolerance: immunologic mechanisms and treatment of animal and human organ-specific autoimmune diseases by oral administration of autoantigens. Annu Rev Immunol. 1994; 12:809-837. [PubMed: 8011298]

89. Bitar DM, Whitacre CC. Suppression of experimental autoimmune encephalomyelitis by the oral administration of myelin basic protein. Cell Immunol. 1988; 112:364-370. [PubMed: 2451570]

90. Meyer AL, Benson JM, Gienapp IE, Cox KL, Whitacre CC. Suppression of murine chronic relapsing experimental autoimmune encephalomyelitis by the oral administration of myelin basic protein. J Immunol. 1996; 157:4230-4238. [PubMed: 8892661]

91. Higgins PJ, Weiner HL. Suppression of experimental autoimmune encephalomyelitis by oral administration of myelin basic protein and its fragments. Immunol. 1988; 140:440-445.

92. Javed NH, Gienapp IE, Cox KL, Whitacre CC. Exquisite peptide specificity of oral tolerance in experimental autoimmune encephalomyelitis. J Immunol. 1995; 155:1599-1605. [PubMed: 7543526] 
93. al-Sabbagh A, Miller A, Santos LM, Weiner HL. Antigen-driven tissue-specific suppression following oral tolerance: orally administered myelin basic protein suppresses proteolipid proteininduced experimental autoimmune encephalomyelitis in the SJL mouse. Eur J Immunol. 1994; 24:2104-2109. [PubMed: 7522160]

94. Karpus WJ, Kennedy KJ, Smith WS, Miller SD. Inhibition of relapsing experimental autoimmune encephalomyelitis in SJL mice by feeding the immunodominant PLP139-151 peptide. J Neurosci Res. 1996; 45:410-423. [PubMed: 8872901]

95. Faria AM, Weiner HL. Oral tolerance. Immunol Rev. 2005; 206:232-259. [PubMed: 16048553]

96. Bai XF, Shi FD, Xiao BG, Li HL, van der Meide PH, Link H. Nasal administration of myelin basic protein prevents relapsing experimental autoimmune encephalomyelitis in DA rats by activating regulatory cells expressing IL-4 and TGF-beta mRNA. J Neuroimmunol. 1997; 80:65-75. [PubMed: 9413260]

97. Bai XF, Li HL, Shi FD, Liu JQ, Xiao BG, Van der Meide PH, Link H. Complexities of applying nasal tolerance induction as a therapy for ongoing relapsing experimental autoimmune encephalomyelitis (EAE) in DA rats. Clin Exp Immunol. 1998; 111:205-210. [PubMed: 9472683]

98. Metzler B, Wraith DC. Mucosal tolerance in a murine model of experimental autoimmune encephalomyelitis. Ann N Y Acad Sci. 1996; 778:228-242. [PubMed: 8610976]

99. Anderton SM, Wraith DC. Hierarchy in the ability of T cell epitopes to induce peripheral tolerance to antigens from myelin. Eur J Immunol. 1998; 28:1251-1261. [PubMed: 9565365]

100. Leadbetter EA, Bourque CR, Devaux B, Olson CD, Sunshine GH, Hirani S, Wallner BP, Smilek DE, Happ MP. Experimental autoimmune encephalomyelitis induced with a combination of myelin basic protein and myelin oligodendrocyte glycoprotein is ameliorated by administration of a single myelin basic protein peptide. J Immunol. 1998; 161:504-512. [PubMed: 9647262]

101. Staykova MA, Simmons RD, Willenborg DO. Infusion of soluble myelin basic protein protects long-term against induction of experimental autoimmune encephalomyelitis. Immunol Cell Biol. 1997; 75:54-64. [PubMed: 9046435]

102. Gaur A, Wiers B, Liu A, Rothbard J, Fathman CG. Amelioration of autoimmune encephalomyelitis by myelin basic protein synthetic peptide-induced anergy. Science. 1992; 258:1491-1494. [PubMed: 1279812]

103. Warren KG, Catz I, Ferenczi LZ, Krantz MJ. Intravenous synthetic peptide MBP8298 delayed disease progression in an HLA Class II-defined cohort of patients with progressive multiple sclerosis: results of a 24-month double-blind placebo-controlled clinical trial and 5 years of follow-up treatment. Eur J Neurol. 2006; 13:887-895. [PubMed: 16879301]

104. Warren KG, Catz I, Wucherpfennig KW. Tolerance induction to myelin basic protein by intravenous synthetic peptides containing epitope P85 VVHFFKNIVTP96 in chronic progressive multiple sclerosis. J Neurol Sci. 1997; 152:31-38. [PubMed: 9395124]

105. Bynoe MS, Evans JT, Viret C, Janeway CA Jr. Epicutaneous immunization with autoantigenic peptides induces $\mathrm{T}$ suppressor cells that prevent experimental allergic encephalomyelitis. Immunity. 2003; 19:317-328. [PubMed: 14499108]

106. Szczepanik M, Tutaj M, Bryniarski K, Dittel BN. Epicutaneously induced TGF-beta-dependent tolerance inhibits experimental autoimmune encephalomyelitis. J Neuroimmunol. 2005; 164:105-114. [PubMed: 15899524]

107. Jurynczyk M, Walczak A, Jurewicz A, Jesionek-Kupnicka D, Szczepanik M, Selmaj K. Immune regulation of multiple sclerosis by transdermally applied myelin peptides. Ann Neurol. 2010; 68:593-601. [PubMed: 21031576]

108. Santambrogio L, Sato AK, Fischer FR, Dorf ME, Stern LJ. Abundant empty class II MHC molecules on the surface of immature dendritic cells. Proc Natl Acad Sci U S A. 1999; 96:15050-15055. [PubMed: 10611336]

109. Miller SD, Turley DM, Podojil JR. Antigen-specific tolerance strategies for the prevention and treatment of autoimmune disease. Nat Rev Immunol. 2007; 7:665-677. [PubMed: 17690713]

110. Kumar V, Urban JL, Horvath SJ, Hood L. Amino acid variations at a single residue in an autoimmune peptide profoundly affect its properties: T-cell activation, major histocompatibility complex binding, and ability to block experimental allergic encephalomyelitis. Proc Natl Acad Sci U S A. 1990; 87:1337-1341. [PubMed: 1689484] 
111. Karin N, Mitchell DJ, Brocke S, Ling N, Steinman L. Reversal of experimental autoimmune encephalomyelitis by a soluble peptide variant of a myelin basic protein epitope: $\mathrm{T}$ cell receptor antagonism and reduction of interferon gamma and tumor necrosis factor alpha production. J Exp Med. 1994; 180:2227-2237. [PubMed: 7525850]

112. Gaur A, Boehme SA, Chalmers D, Crowe PD, Pahuja A, Ling N, Brocke S, Steinman L, Conlon PJ. Amelioration of relapsing experimental autoimmune encephalomyelitis with altered myelin basic protein peptides involves different cellular mechanisms. J Neuroimmunol. 1997; 74:149158. [PubMed: 9119968]

113. Nicholson LB, Greer JM, Sobel RA, Lees MB, Kuchroo VK. An altered peptide ligand mediates immune deviation and prevents autoimmune encephalomyelitis. Immunity. 1995; 3:397-405. [PubMed: 7584131]

114. Nicholson LB, Murtaza A, Hafler BP, Sette A, Kuchroo VK. A T cell receptor antagonist peptide induces T cells that mediate bystander suppression and prevent autoimmune encephalomyelitis induced with multiple myelin antigens. Proc Natl Acad Sci U S A. 1997; 94:9279-9284. [PubMed: 9256473]

115. Young DA, Lowe LD, Booth SS, Whitters MJ, Nicholson L, Kuchroo VK, Collins M. IL-4, IL-10, IL-13, and TGF-beta from an altered peptide ligand-specific Th2 cell clone down-regulate adoptive transfer of experimental autoimmune encephalomyelitis. J Immunol. 2000; 164:35633572. [PubMed: 10725711]

116. Kuchroo VK, Greer JM, Kaul D, Ishioka G, Franco A, Sette A, Sobel RA, Lees MB. A single TCR antagonist peptide inhibits experimental allergic encephalomyelitis mediated by a diverse T cell repertoire. J Immunol. 1994; 153:3326-3336. [PubMed: 7522258]

117. Franco A, Southwood S, Arrhenius T, Kuchroo VK, Grey HM, Sette A, Ishioka GY. T cell receptor antagonist peptides are highly effective inhibitors of experimental allergic encephalomyelitis. Eur J Immunol. 1994; 24:940-946. [PubMed: 7512036]

118. Crowe PD, Qin Y, Conlon PJ, Antel JP. NBI-5788, an altered MBP83-99 peptide, induces a Thelper 2-like immune response in multiple sclerosis patients. Ann Neurol. 2000; 48:758-765. [PubMed: 11079539]

119. Bielekova B, Goodwin B, Richert N, Cortese I, Kondo T, Afshar G, Gran B, Eaton J, Antel J, Frank JA, McFarland HF, Martin R. Encephalitogenic potential of the myelin basic protein peptide (amino acids 83-99) in multiple sclerosis: results of a phase II clinical trial with an altered peptide ligand. Nat Med. 2000; 6:1167-1175. [PubMed: 11017150]

120. Kappos L, Comi G, Panitch H, Oger J, Antel J, Conlon P, Steinman L. Induction of a nonencephalitogenic type $2 \mathrm{~T}$ helper-cell autoimmune response in multiple sclerosis after administration of an altered peptide ligand in a placebo-controlled, randomized phase II trial. The Altered Peptide Ligand in Relapsing MS Study Group. Nat Med. 2000; 6:1176-1182. [PubMed: 11017151]

121. Aharoni R, Teitelbaum D, Arnon R, Sela M. Copolymer 1 acts against the immunodominant epitope $82-100$ of myelin basic protein by $\mathrm{T}$ cell receptor antagonism in addition to major histocompatibility complex blocking. Proc Natl Acad Sci U S A. 1999; 96:634-639. [PubMed: 9892685]

122. Ruiz PJ, DeVoss JJ, Nguyen LV, Fontoura PP, Hirschberg DL, Mitchell DJ, Garcia KC, Steinman L. Immunomodulation of experimental autoimmune encephalomyelitis with ordered peptides based on MHC-TCR binding motifs. J Immunol. 2001; 167:2688-2693. [PubMed: 11509612]

123. Illes Z, Stern JN, Reddy J, Waldner H, Mycko MP, Brosnan CF, Ellmerich S, Altmann DM, Santambrogio L, Strominger JL, Kuchroo VK. Modified amino acid copolymers suppress myelin basic protein 85-99-induced encephalomyelitis in humanized mice through different effects on T cells. Proc Natl Acad Sci U S A. 2004; 101:11749-11754. [PubMed: 15292513]

124. Stern JN, Illes Z, Reddy J, Keskin DB, Fridkis-Hareli M, Kuchroo VK, Strominger JL. Peptide 15-mers of defined sequence that substitute for random amino acid copolymers in amelioration of experimental autoimmune encephalomyelitis. Proc Natl Acad Sci U S A. 2005; 102:1620-1625. [PubMed: 15665083]

125. Munari L, Lovati R, Boiko A. Therapy with glatiramer acetate for multiple sclerosis. Cochrane Database Syst Rev. 2004:CD004678. [PubMed: 14974077] 
126. Manikwar P, Kiptoo P, Badawi AH, Buyuktimkin B, Siahaan TJ. Antigen-specific blocking of CD4-specific immunological synapse formation using BPI and current therapies for autoimmune diseases. Med Res Rev. 2011

127. Corper AL, Stratmann T, Apostolopoulos V, Scott CA, Garcia KC, Kang AS, Wilson IA, Teyton L. A structural framework for deciphering the link between I-Ag7 and autoimmune diabetes. Science. 2000; 288:505-511. [PubMed: 10775108]

128. Xu CR, Yusuf-Makagiansar H, Hu Y, Jois SD, Siahaan TJ. Structural and ICAM-1-docking properties of a cyclic peptide from the I-domain of LFA-1: an inhibitor of ICAM-1/LFA-1mediated T-cell adhesion. J Biomol Struct Dyn. 2002; 19:789-799. [PubMed: 11922836]

129. Casasnovas JM, Stehle T, Liu JH, Wang JH, Springer TA. A dimeric crystal structure for the Nterminal two domains of intercellular adhesion molecule-1. Proc Natl Acad Sci U S A. 1998; 95:4134-4139. [PubMed: 9539702]

130. Bella J, Kolatkar PR, Marlor CW, Greve JM, Rossmann MG. The structure of the two aminoterminal domains of human ICAM-1 suggests how it functions as a rhinovirus receptor and as an LFA-1 integrin ligand. Proc Natl Acad Sci U S A. 1998; 95:4140-4145. [PubMed: 9539703]

131. Murray JS, Oney S, Page JE, Kratochvil-Stava A, Hu Y, Makagiansar IT, Brown JC, Kobayashi N, Siahaan TJ. Suppression of type 1 diabetes in NOD mice by bifunctional peptide inhibitor: modulation of the immunological synapse formation. Chem Biol Drug Des. 2007; 70:227-236. [PubMed: 17718717]

132. Kobayashi N, Kobayashi H, Gu L, Malefyt T, Siahaan TJ. Antigen-specific suppression of experimental autoimmune encephalomyelitis by a novel bifunctional peptide inhibitor. $\mathrm{J}$ Pharmacol Exp Ther. 2007; 322:879-886. [PubMed: 17522343]

133. Kobayashi N, Kiptoo P, Kobayashi H, Ridwan R, Brocke S, Siahaan TJ. Prophylactic and therapeutic suppression of experimental autoimmune encephalomyelitis by a novel bifunctional peptide inhibitor. Clin Immunol. 2008; 129:69-79. [PubMed: 18676182]

134. Ridwan R, Kiptoo P, Kobayashi N, Weir S, Hughes M, Williams T, Soegianto R, Siahaan TJ. Antigen-specific suppression of experimental autoimmune encephalomyelitis by a novel bifunctional peptide inhibitor: structure optimization and pharmacokinetics. J Pharmacol Exp Ther. 2010; 332:1136-1145. [PubMed: 20026673]

135. Zhao H, Kiptoo P, Williams TD, Siahaan TJ, Topp EM. Immune response to controlled release of immunomodulating peptides in a murine experimental autoimmune encephalomyelitis (EAE) model. J Control Release. 2010; 141:145-152. [PubMed: 19748537]

136. Srinivasan M, Gienapp IE, Stuckman SS, Rogers CJ, Jewell SD, Kaumaya PT, Whitacre CC. Suppression of experimental autoimmune encephalomyelitis using peptide mimics of CD28. J Immunol. 2002; 169:2180-2188. [PubMed: 12165548]

137. Chen J, He Q, Zhang R, Chu Y, Wang Y, Liu Q, Xiong S. Allogenic donor splenocytes pretreated with antisense peptide against B7 prolong cardiac allograft survival. Clin Exp Immunol. 2004; 138:245-250. [PubMed: 15498033]

138. Marini JC, Jameson BA, Lublin FD, Korngold R. A CD4-CDR3 peptide analog inhibits both primary and secondary autoreactive $\mathrm{CD} 4+\mathrm{T}$ cell responses in experimental allergic encephalomyelitis. J Immunol. 1996; 157:3706-3715. [PubMed: 8871674]

139. Edling AE, Choksi S, Huang Z, Korngold R. Effect of a cyclic heptapeptide based on the human $\mathrm{CD} 4$ domain $1 \mathrm{CC}^{\prime}$ loop region on murine experimental allergic encephalomyelitis: inhibition of both primary and secondary responses. J Neuroimmunol. 2001; 112:115-128. [PubMed: 11108940]

140. Iyer S, Lahana R, Buelow R. Rational design and development of RDP58. Curr Pharm Des. 2002; 8:2217-2229. [PubMed: 12369864]

141. Cuturi MC, Christoph F, Woo J, Iyer S, Brouard S, Heslan JM, Pignon P, Soulillou JP, Buelow R. RDP1258, a new rationally designed immunosuppressive peptide, prolongs allograft survival in rats: analysis of its mechanism of action. Mol Med. 1999; 5:820-832. [PubMed: 10666482]

142. Iyer S, Woo J, Cornejo MC, Gao L, McCoubrey W, Maines M, Buelow R. Characterization and biological significance of immunosuppressive peptide D2702.75-84(E --> V) binding protein. Isolation of heme oxygenase-1. J Biol Chem. 1998; 273:2692-2697. [PubMed: 9446574] 
143. Liu Y, Zhu B, Luo L, Li P, Paty DW, Cynader MS. Heme oxygenase-1 plays an important protective role in experimental autoimmune encephalomyelitis. Neuroreport. 2001; 12:18411845. [PubMed: 11435909]

144. Liu Y, Zhu B, Wang X, Luo L, Li P, Paty DW, Cynader MS. Bilirubin as a potent antioxidant suppresses experimental autoimmune encephalomyelitis: implications for the role of oxidative stress in the development of multiple sclerosis. J Neuroimmunol. 2003; 139:27-35. [PubMed: 12799017]

145. DeVry CG, Valdez M, Gao L, Wang J, Kotsch K, Volk HD, Bechmann I, Buelow R, Iyer S. RDP58, a novel immunomodulatory peptide, ameliorates clinical signs of disease in the Lewis rat model of acute experimental autoimmune encephalomyelitis. J Neuroimmunol. 2004; 152:33-43. [PubMed: 15223235]

146. Brodsky B, Erlanger-Rosengarten A, Proscura E, Shapira E, Wormser U. From topical antidote against skin irritants to a novel counter-irritating and anti-inflammatory peptide. Toxicol Appl Pharmacol. 2008; 229:342-350. [PubMed: 18400241]

147. Shapira E, Brodsky B, Proscura E, Nyska A, Erlanger-Rosengarten A, Wormser U. Amelioration of experimental autoimmune encephalitis by novel peptides: involvement of T regulatory cells. $\mathrm{J}$ Autoimmun. 2010; 35:98-106. [PubMed: 20434883]

148. Zheng HM, Jiang Y, Wang JR, Gong XL, Guo BY. Mimic peptides bonding specifically with the first and second extracellular loops of the CC chemokine receptor 5 derived from a phage display peptide library are potent inhibitors of experimental autoimmune encephalomyelitis. Inflamm Res. 2011; 60:759-767. [PubMed: 21533529]

149. Hamann I, Zipp F, Infante-Duarte C. Therapeutic targeting of chemokine signaling in Multiple Sclerosis. J Neurol Sci. 2008; 274:31-38. [PubMed: 18706659]

150. Bielekova B, Becker BL. Monoclonal antibodies in MS: mechanisms of action. Neurology. 2010; 74(Suppl 1):S31-40. [PubMed: 20038761]

151. Srinivasan M, Janardhanam S. Novel p65 binding GILZ peptide suppresses experimental autoimmune encephalomyelitis. J Biol Chem. 2011

152. Ayroldi E, Migliorati G, Bruscoli S, Marchetti C, Zollo O, Cannarile L, D’Adamio F, Riccardi C. Modulation of T-cell activation by the glucocorticoid-induced leucine zipper factor via inhibition of nuclear factor kappaB. Blood. 2001; 98:743-753. [PubMed: 11468175]

153. Marta M. Toll-like receptors in multiple sclerosis mouse experimental models. Ann N Y Acad Sci. 2009; 1173:458-462. [PubMed: 19758186]

154. Weiner HL. Multiple sclerosis is an inflammatory T-cell-mediated autoimmune disease. Arch Neurol. 2004; 61:1613-1615. [PubMed: 15477521]

155. Racke MK, Drew PD. Toll-like receptors in multiple sclerosis. Curr Top Microbiol Immunol. 2009; 336:155-168. [PubMed: 19688333]

156. Gambuzza M, Licata N, Palella E, Celi D, Foti Cuzzola V, Italiano D, Marino S, Bramanti P. Targeting Toll-like receptors: Emerging therapeutics for multiple sclerosis management. J Neuroimmunol. 2011

157. Bochner BS, Lichtenstein LM. Anaphylaxis. N Engl J Med. 1991; 324:1785-1790. [PubMed: 1789822]

158. Martin TR, Galli SJ, Katona IM, Drazen JM. Role of mast cells in anaphylaxis. Evidence for the importance of mast cells in the cardiopulmonary alterations and death induced by anti-IgE in mice. J Clin Invest. 1989; 83:1375-1383. [PubMed: 2784802]

159. Smith CE, Eagar TN, Strominger JL, Miller SD. Differential induction of IgE-mediated anaphylaxis after soluble vs. cell-bound tolerogenic peptide therapy of autoimmune encephalomyelitis. Proc Natl Acad Sci U S A. 2005; 102:9595-9600. [PubMed: 15983366]

160. Pedotti R, Mitchell D, Wedemeyer J, Karpuj M, Chabas D, Hattab EM, Tsai M, Galli SJ, Steinman L. An unexpected version of horror autotoxicus: anaphylactic shock to a self-peptide. Nat Immunol. 2001; 2:216-222. [PubMed: 11224520]

161. Katz DH, Bargatze RF, Bogowitz CA, Katz LR. Regulation of IgE antibody production by serum molecules. IV. Complete Freund's adjuvant induces both enhancing and suppressive activities detectable in the serum of low and high responder mice. J Immunol. 1979; 122:2184-2190. [PubMed: 448123] 


\section{Highlights}

1. The immunological basis for the onset of MS is summarized.

2. Specific and non-specific peptides tested in EAE and in humans are discussed.

3. Some problems and potential solutions with these novel therapies are addressed. 


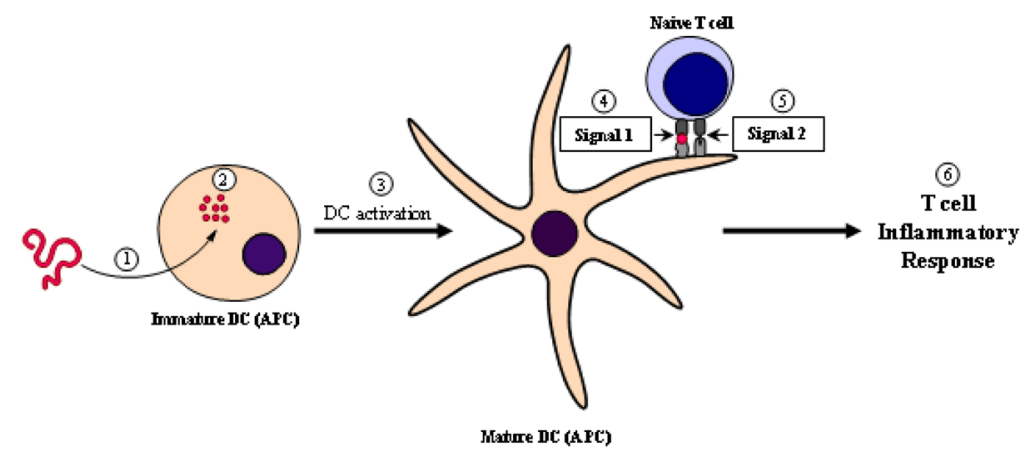

Figure 1.

Activation of a T cell inflammatory response. 1) A steady-state APC such as an immature DC internalizes an insoluble protein antigen. 2) The antigen is then processed and broken down into immuno-dominant peptides that can be presented by the MHC-II molecule on the surface of the APC. 3) Internalization and processing of the antigen triggers the activation of the DC, thus forming a mature $\mathrm{DC}(\mathrm{mDC}) .4)$ Presentation of the antigen by the $\mathrm{mDC}$ in the context of the MHC-II molecule to the TCR on a naïve T cell is known as Signal 1. 5) mDC expresses costimulatory molecules which delivers an activation signal to naïve $\mathrm{T}$ cells this is known as Signal 2. 6) The presentation of an antigen in presence of costimulatory signals triggers the development of a $\mathrm{T}$ cell inflammatory response towards that antigen. 


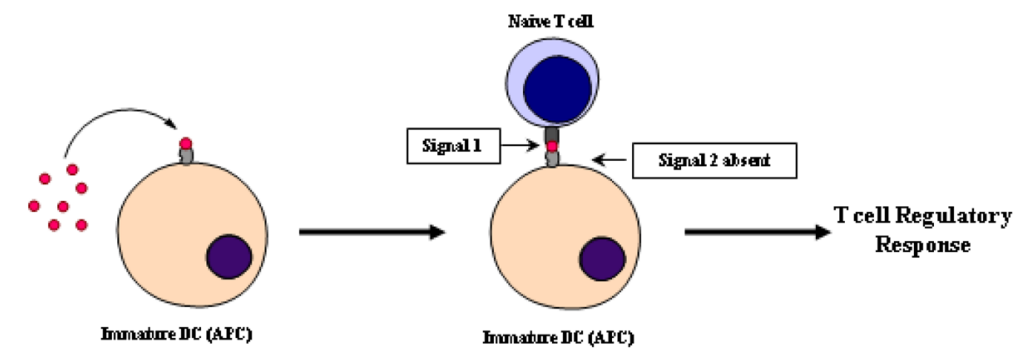

Figure 2.

Administration of soluble peptide antigens induces a $\mathrm{T}$ cell regulatory immune response. Soluble peptides can bind directly to empty MHC-II molecules on the surface of iDC avoiding internalization and processing of the antigen. Presentation of the antigen in absence of Signal 2 by an iDC leads to an antigen-specific regulatory response. 


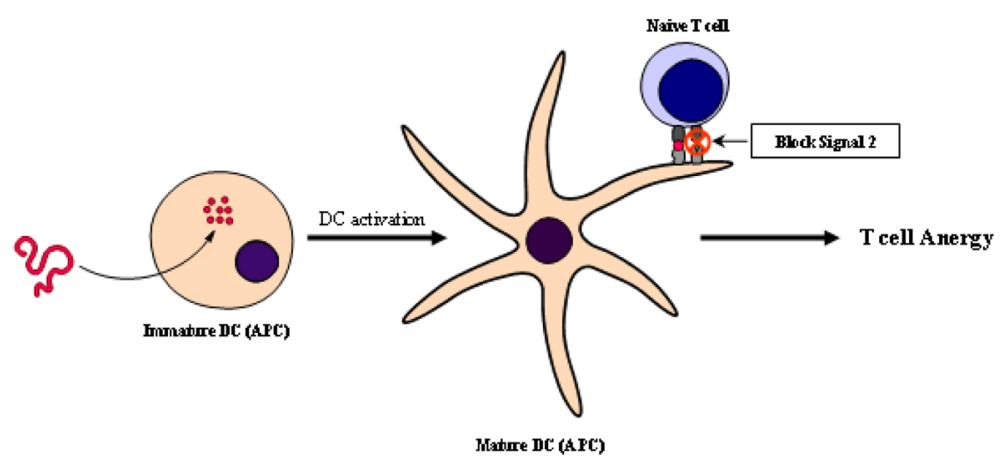

Figure 3.

Presentation of antigen with Signal 2 blockade causes improper activation of $\mathrm{T}$ cells thus leading to T cell anergy. 